\title{
Results of Lime and Minor-Element Fertilizer Research in Puerto Rico, 194,9-50
}

\author{
Pablo Landrau, Jr., and George Samuels ${ }^{1}$
}

\section{INTRODUCTION}

About a hundred years ago Julius Sachs demonstrated that such elements as sulfur, calcium, magnesium, and iron were essential to plant growth. Less than 25 years ago, such minor elements as copper and zinc were being used by the farmer to correct deficiencies in citrus and vegetable crops grown on peat or muck soils. Today, the use of minor-element fertilizers for certain crops with high requirements for a specific minor element, or in soils lacking a good available supply of the element, is a common practice in many parts of the world.

Since minor-element fertilization has benefitted so many crops and soils in the United States, it was only natural that agriculturists in Puerto Rico began to ask whether they would prove beneficial to Puerto Rican agriculture. The pineapple growers were first to recognize the specific benefit of minor-element fertilizers. Work by Schappelle (17), ${ }^{2}$ Hopkins (8), and Ramírez Silva (14) showed that an iron chlorosis was present in most pineapples growing in Puerto Rico. The growers found that the use of iron sprays were necessary to obtain satisfactory pineapple yields, and growth, especially in soils with a $\mathrm{pH}$ above 5.5 (13).

As early as 1927, attempts were made to increase the sucrose content of sugarcane by applying manganese salts to the soil, but the results were negligible. Again in 1941-42, an experiment was conducted to try to correct a cane chlorosis at Central Guánica on a Fraternidad clay, a calcareous soil type, with treatments including sulfur, copper, iron, manganese, and molasses. The use of 1,000 pounds of sulfur produced the highest yields. In 1949, full-scale field experiments were initiated in minor-element fertilizer research beginning with an experiment on sugarcane at Guánica.

\section{OBJECTIVE}

It is the purpose of this paper to give the results of minor-element fertilizer experiments conducted by the Agronomy and Horticulture Department of the Agricultural Experiment Station of the University of Puerto Rico during 1949-54, and to summarize the results in terms of practical application to specific crops or soils in Puerto Rico.

${ }^{1}$ Associate Agronomist and Agronomist, respectively, Agricultural Experiment Station, University of Puerto Rico, Río Piedras, P. R.

2 Numbers in parentheses refer to Literature Cited, p. 234. 


\section{PROCEDURES}

All experiments conducted in this work were laid out in the field according to well-known experimental designs with sufficient replications to insure reliable statistical analysis. The majority of the experiments were replicated nine times. The experimental designs were mainly triple lattices, and in a few experiments, randomized blocks. Most of the experiments were so designed that both major- and minor-element fertilizers were studied in the same experiment. In all experiments the minor-element treatments as well as the check treatment received adequate supplies of the major-fertilizer elements (N-P-K). In testing the need for a particular minor element, the treatment consisted in adding the minor element to the soil along with a major-element fertilizer and comparing the yield obtained with that of the treatments where only the major-element fertilizer was added.

\section{RESULTS}

The results of the experiments will be grouped under the specific crops rather than by the minor elements applied. It is felt that this will give a more comprehensive picture of the minor-element fertilizer needs of the various crops of Puerto Rico.

\section{SUGARCANE}

The majority of the work with minor-element fertilizers has been centered around sugarcane, since this crop is the main agricultural enterprise in Puerto Rico and is grown almost everywhere in the Island.

The results of eight experiments carried out with sugarcane are summarized in table 1. In general, no minor-element fertilizer gave appreciable yield increases in all experiments. However, certain significant yield increases were realized for particular soils. Considering each fertilizer element used, the following results were obtained:

\section{Calcium}

For the acid soils ( $\mathrm{pH}$ below 5.5) such as the Lares clay, Via silty clay, and some areas of the Coto clay, the use of calcium as lime $\left(\mathrm{CaCO}_{3}\right)$ produced significant increases in yield of available $96^{\circ}$ sugar per acre. This increase was due mainly to an increase in tons of cane per acre, rather than sucrose-percent-cane. Lime was of no value in soils with a $\mathrm{pH}$ above 6 (Tiburones muck and Toa silty clay loam).

Experiments reported in the literature have shown a variable response to the lime added. Doty, in Hawaii (7), found poor juice purities and poor quality ratios when lime was applied; however, water-culture experiments (2) have shown that calcium-deficient canes had greatly increased 


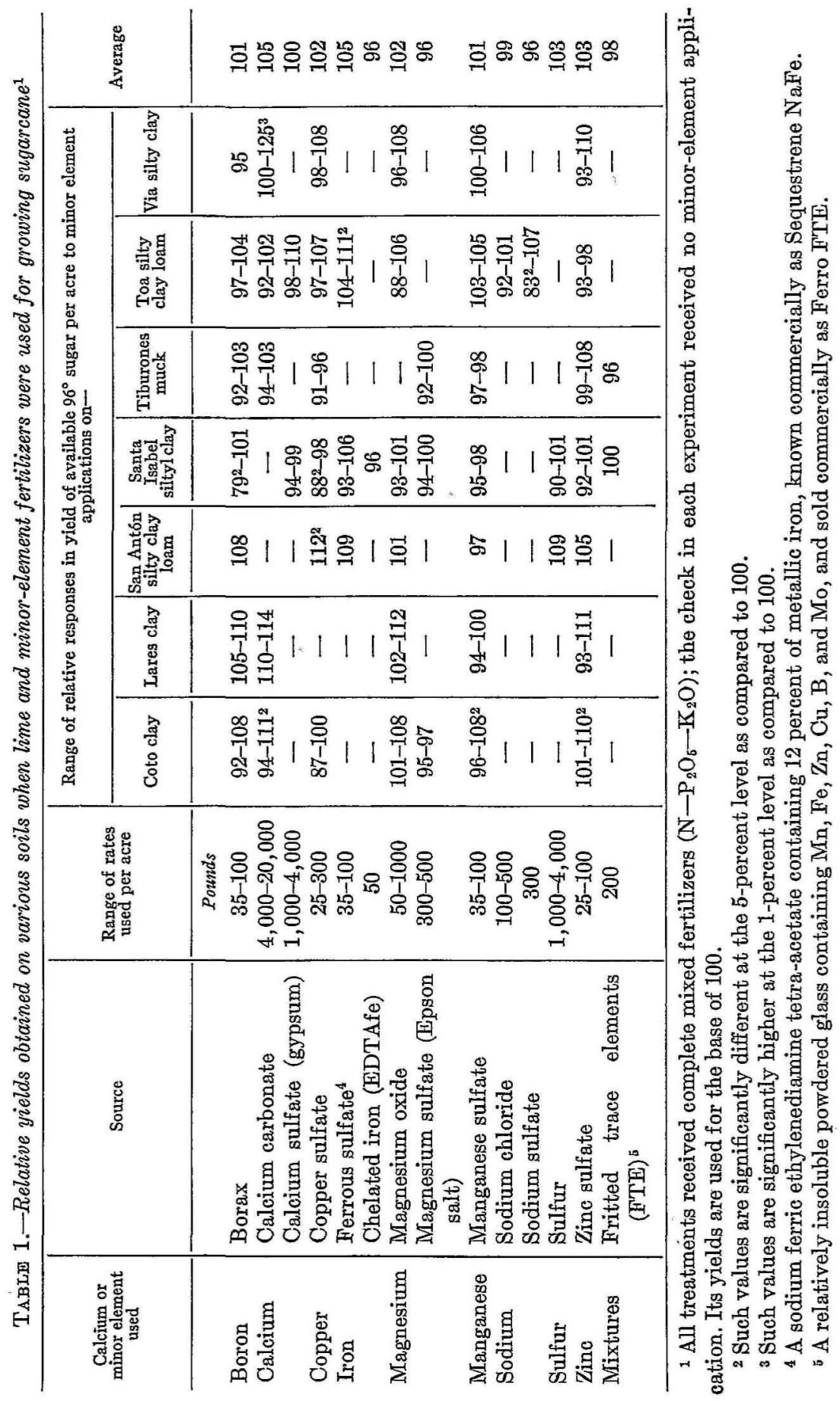


sucrose contents in stalk and leaf. Liming has proved beneficial on the very acid Pegassy clays of British Guiana ( $\mathrm{pH}$ below 4).

The question arises in liming sugarcane as to whether the beneficial effect of liming occurs because of a correction of soil $\mathrm{pH}$ or because of the calcium added as a needed nutritive plant element. In two of the experiments calcium was added as calcium sulfate (gypsum) rather than as lime $\left(\mathrm{CaCO}_{3}\right)$. No significant yield responses were obtained (table 1). Unfortunately, the soils tested had $\mathrm{pH}$ values of over 6 . McGeorge showed that acidity or the $\mathrm{H}$ ion by itself had no harmful influence on cane growth in the infertile acid cane soils of mauka fields in Hawaii (12). In the majority of the cases where poor growth was obtained in very acid soils the presence of toxic amounts of aluminum salts retarded growth. Liming in these cases fixed the aluminum in an insoluble form by raising the $\mathrm{pH}$. The authors have seen evidence . of aluminum toxicity on the roots of the cane plant in Puerto Rico, growing on a Coloso clay of low acidity ( $\mathrm{pH}$ 3.8) with poor drainage. This condition was corrected by liming and improving drainage.

It appears that the sugarcane plant is able to obtain sufficient calcium for its needs over a rather wide $\mathrm{pH}$ range in Puerto Rico (pH 5.5 to 8). Lime has given some responses to cane yields in soils with a pH below 5.5. At present it cannot be said whether this response is due to the correction of $\mathrm{pH}$ or to direct effects of the calcium added. However, in these experiments, it should be remembered that calcium was also added in the form of calcium sulfate in the superphosphate used. Also large quantities of calcium are returned to the soil by the cane trash and roots (16). Hence credit for beneficial effects of liming appears more likely to be due to a correction of very low $\mathrm{pH}$ values and the resultant aluminum toxicity rather than to the addition of needed nutritional calcium to the plant.

\section{Boron}

The general response of sugarcane to boron fertilization has been variable but rather negligible. In none of the experiments were cane yields increased significantly, and in one experiment (Santa Isabel silty clay, table 1), yields were significantly reduced from the use of 100 pounds of borax per acre. Aside from this one instance rates of up to 100 pounds of borax per acre (11 pounds of boron per acre) did not produce any injurious influence on cane yields in the soils on which they were applied, which were, generally, silty-clay loams to clays. Martin (11) found that although boron deficiencies could be produced in sugarcane growing in nutrient solutions, only 0.22 p.p.m. of boron was needed to prevent this. Borden in Hawaii (3) obtained no yield increase with boron (as boric acid) at 28 and 112 pounds of boron per acre. With 112 pounds of boron per acre a reduced yield was obtained of the $H$. 32-8560 variety on a makiki soil. 


\section{Copper}

The response of sugarcane to fertilizers containing copper salts was highly variable. In one case, with a ratoon crop of cane on a San Antón silty clay loam under irrigation, the use of 25 pounds of copper sulfate per acre gave a significant increase in yield. On the other hand, a closely related soil, a Santa Isabel silty clay, also found on the southern coast of Puerto Rico, produced a significant decrease in yield without irrigation when 100 pounds of copper sulfate per acre was used. In both cases, cane tonnages were influenced more than sucrose-percent-cane.

The general response to copper sulfate was low. Although organic soils in New Jersey and Florida have shown favorable responses to copper fertilization, the Tiburones muck, an organic soil of Puerto Rico (table 1) showed no response of sugarcane to copper.

\section{Iron}

Of all the minor-element fertilizers used, the highest average increase was produced by the application of iron as ferrous sulfate. In one instance of a first ratoon on a Toa silty-clay loam, 100 pounds of ferrous sulfate per acre gave a very significant increase in sucrose-percent-cane. Applied as a spray, 10 pounds of ferrous sulfate per 100 gallons of water, it also increased yields on a San Antón silty-clay loam, a soil with a $\mathrm{pH}$ above 7. The cane plots showed an iron chlorosis in the leaf which disappeared when the iron sulfate was applied. Doty (6) reported improved yields of cane on coral soils of Hawaii where iron sulfate sprays were used. The use of 50 pounds per acre of chelated iron in the soil on a ratoon crop grown on an unirrigated Santa Isabel silty clay (table 1) failed to give yield responses.

\section{Magnesium}

On acid soils with a $\mathrm{pH}$ below 6 , such as Coto clay, Lares clay, or Vía silty clay, magnesium in the form of the oxide gave some yield increases, the average relative yield having been 105 . However, no such average increases were found for soils with $\mathrm{pH} 6$ and above. The more soluble magnesium sulfate produced no yield increase. In one instance, on a Coto clay, (table 1), increases were obtained with the less soluble oxide, but not with the more soluble sulfate of magnesium. A significant increase in sucrosepercent-cane, but not in tons of cane, was obtained for the first ratoon. The pattern was just reversed for the second ratoon on the Lares clay. In general, magnesium gave a variable influence on yield.

\section{Manganese}

The average response to manganese fertilizers was almost negligible. In only one instance was a significant response obtained. This was for the 
plant crop only (12 months) grown on a Coto clay. No significant responses were obtained in the ratoon crops. No response was obtained to manganese fertilizers on the San Antón silty clay loam at Guánica. Preliminary observational experiments in this area 5 years before also failed to show responses.

\section{Sodium}

Sodium both as the chloride and sulfate failed to produce any significant increase in sugar per acre on a Toa silty clay loam. The use of sodium sulfate at a rate of 300 pounds per acre reduced yields significantly, although the use of sodium chloride up to 500 pounds per acre gave no detrimental effects. Borden in Hawaii (4) found that sodium as sodium chloride failed to increase potash efficiency. On a low $\mathrm{K}$ level sodium chloride lowered Brix and polarization in crusher juice and gave less sugar; and on a high $\mathrm{K}$ level, sodium chloride produced no effect on quality or yield.

\section{Sulfur}

On soils with a pH above 7, such as San Antón silty clay loam and a Santa Isabel silty clay, the use of sulfur failed to give any increases in yields. The $\mathrm{pH}$ values were not appreciably decreased by the sulfur additions for the duration of the experiment.

\section{Zinc}

The use of zinc sulfate produced variable results on sugar yields. Some yield responses were obtained on the more acid soils. In one case, a 12-month plant cane on a Coto clay, the yield of available $96^{\circ}$ sugar per acre was significantly increased. However, the yield increases were not significant for the ratoons. Even the use of extreme precautions in solution culture failed to produce a zinc deficiency in cane in nutrient studies made in $\mathrm{Ha}$ waii (1).

\section{Mixture of elements}

The use of a fritted trace-element mixture containing copper, zinc, magnesium, boron, manganese, and iron in the form of relatively insoluble powdered glass failed to give increases in sugar per acre for a Santa Isabel silty clay or a Tiburones muck.

\section{ACEROLA}

A very highly significant response has been obtained from the use of lime for acerola on a Sabana Seca sandy clay. The soil, with an original $\mathrm{pH}$ of 4.5, gave a relative increase in yield of over 400 percent (see table 2) when 2 tons of lime per acre were added. Chelated iron did not increase yields significantly and the use of fritted trace elements decreased yields. 


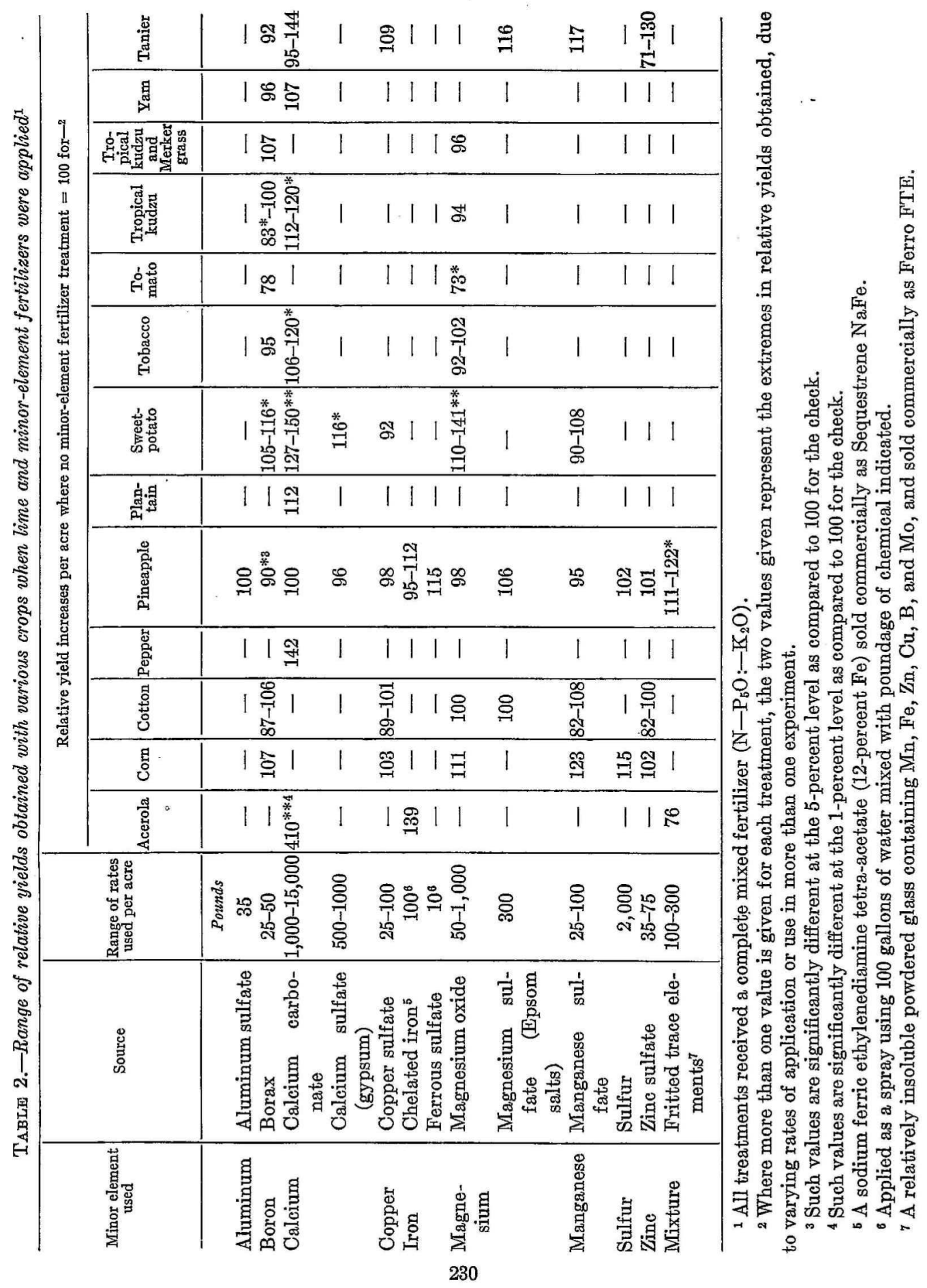


The response to lime in commercial acerola orchards has been noted by the authors. Visual symptoms of calcium deficiency were noted in unlimed acerola trees growing on a Sabana Seca sandy clay ( $\mathrm{pH}$ 4.2). These symptoms were similar to those developed on calcium-deficient acerolas growing in sand culture in the greenhouse (5). The leaves showed a yellowing at the tips and along the marginal areas. There was a severe burning at the tip of the leaf when the deficiency was more acute.

\section{PINEAPPLE}

Iron sprays and a fritted trace-element fertilizer gave relative increases in pineapple yields. The chelated iron source was no better than ferrous sulfate in increasing yields (table 2). The use of fritted trace elements, FTE, a relatively insoluble powdered glass containing manganese, iron, zinc, copper, boron, and molybdenum, did increase yields. It may be that the soil applications of the soluble minor-element fertilizers are leached away before the pineapple plant can make full use of them.

\section{SWEETPOTATO}

Borax, lime, gypsum, and magnesium oxide all raised the yields of sweetpotato significantly (9). When used on a Sabana Seca sandy clay, 500 pounds of gypsum per acre increased sweetpotato yields, as did 30 pounds of borax per acre. For the acid Lares clay, raising the soil $\mathrm{pH}$ with lime (12,500 pounds per acre) gave a yield increase of 50 percent. Magnesium oxide effects were not consistent. Magnesium oxide raised yields significantly when used at 300 pounds per acre with lime on a Lares clay, but not when 600 pounds per acre were used, nor did it benefit yields at the rate of 200 pounds per acre on a Cataño sandy loam.

\section{TOBACCO}

Tobacco gave significant yield increases when lime was applied. The use of 1 ton of lime per acre proved as good as 2 tons on a Juncos clay at Aibonito. Boron or magnesium fertilizers did not increase yields.

\section{TOMATO}

Yields of tomato were lowered when 100 pounds of magnesium oxide or 50 pounds of borax per acre were used on a Coto clay at Isabela. The reduction in yield due to the magnesium oxide in this case was significant at the 5-percent level.

\section{TROPICAI KUDZU}

Liming gave increased yields of tropical kudzu. On a Fajardo clay at Río Piedras, raising the soil $\mathrm{pH}$ from 5.3 to 6.5 with lime increased yields 
of green kudzu forage (10), but not the protein content. At Corozal, on an acid Lares clay ( $\mathrm{pH} 4.5$ ), liming failed to increase kudzu forage production significantly, although the protein contents was significantly increased. The use of 50 pounds of borax per acre reduced yields significantly when applied to the unlimed soil. There was no appreciable yield reduction when borax was used with lime. There was no marked response to magnesium fertilizers for kudzu.

\section{GRAPEFRUIT}

The application of zinc and magnesium sulfate as spray and in the soil relieved grapefruit trees from visual symptoms of deficiency of the abovementioned minor elements. The observations were made at Arecibo on an old grapefruit orchard planted on Sabana Seca sandy clay. The use of the magnesium and zinc sprays corrected a heavy shedding of the leaves on these grapefruit trees.

\section{CROPS SHOWING NO RESPONSE}

Corn showed no significant response to minor-element fertilizers when grown on an unirrigated Santa Isabel silty clay at Lajas (table 2).

No significant responses were obtained from the use of minor-element fertilizers on cotton growing in a Coto clay at Isabela ( $\mathrm{pH}$ 6.5) (table 2).

Liming at the rate of 1 ton per acre failed to give a significant yield increase for peppers when grown on a Juncos clay at Aibonito.

Liming failed to increase the yields of plantain on a Lares clay. Original soil $\mathrm{pH}$ was 4.6, and sufficient lime was added to raise the $\mathrm{pH}$ to 6.2 .

When grown in a mixed stand, tropical kudzu and Merker grass did not respond significantly to boron or magnesium applications on a Fajardo clay at Río Piedras (15).

Neither liming nor borax produced any significant increase in yields of yam (Dioscorea rotundata) when grown on a Lares clay at Utuado.

On an acid Lares clay at Corozal, lime alone or in combination with zinc, magnesium, copper, or magnesium salts failed to increase yields significantly for taniers (Xanthosoma atrovirens).

\section{SUMMMARY}

The effects of lime and minor-element fertilizers on the yield of sugarcane, root crops, legumes, vegetables, cotton, corn, pineapple, and acerola covering different soil types and climatic conditions, were investigated and the following conclusions were drawn from the results:

1. The use of lime on acid soils ( $\mathrm{pH}$ below 5.5) increased yields for the majority of the crops studied. 
2. No response was obtained on the yield of sugarcane with the use of lime on soils with a $\mathrm{pH}$ above 6 .

3. The yield of acerola was increased over 400 percent when lime was applied to a Sabana Seca sandy clay soil (pH 4.5).

4. In general, no consistant yield increases were obtained from the use of manganese sulfate, sodium chloride, sulfur, zinc sulfate, mixtures of minor elements, magnesium oxide, and borax, with the exception of the last two, which gave significant yield increases of sweetpotatoes, when used on a Lares clay and Sabana Seca sandy clay.

5. The use of iron sprays and fritted trace elements gave increases in pineapple yields. Ferrous sulfate and chelated iron proved to be equally effective.

6. Crops showing no response were corn, cotton, peppers, plantains, tropical kudzu and Merker in a mixed stand, yams (Dioscorea rotundata), and taniers (Xanthosoma atrovirens).

\section{RESUMEN}

Los resultados de las investigaciones, llevadas a cabo en distintos tipos de suelos y condiciones de clima, para determinar los efectos de las aplicaciones de cal y elementos menores sobre el rendimiento de la caña de azúcar, y sobre la producción de tubérculos, leguminosas, hortalizas, algodón, maíz, piña y acerola, han motivado las conclusiones siguientes:

1. Los rendimientos de la mayoría de las cosechas bajo estudio aumentaron cuando se usó el carbonato de calcio en aquellos suelos ácidos con un $\mathrm{pH}$ menor de 5.5.

2. La aplicación del carbonato de calcio a suelos de un pH de 6 ó más, no tuvo efecto significativo sobre los rendimientos de la caña de azúcar.

3. La producción de acerolas aumentó un 400 por ciento en la arcilla arenosa Sabana Seca ( $\mathrm{pH} 4.5$ ), cuando se aplicó carbonato de calcio.

4. En general, los resultados no indicaron aumentos continuos mediante el uso de sulfato de manganeso y zinc, cloruro de sodio, azufre, compuestos de elementos menores, óxido de magnesio y borax, con la excepción de estos dos últimos, los cuales aumentaron significativamente los rendimientos de la batata cuando se aplicaron a la arcilla Lares y a la arcilla arenosa Sabana Seca.

5. Los rendimientos de la piña aumentaron mediante las aspersiones de hierro y la aplicación de elementos menores (fritted-trace elements). El sulfato de hierro y el hierro quelado probaron ser igualmente eficaces.

6. Las cosechas que no respondieron a los tratamientos fueron: Maíz, algodón, pimiento, plátano, kudzú trópical y yerba Merker en siembra mixta, ñame (Dioscorea rotundata), y yautía. (Xanthosoma atrovivens). 


\section{LITERATURE CITED}

1. Anonymous, Experiment Station Committee Report 1954, Hawaiian Sugar Planters' Assoc. p. 11, 1954.

2. Baver, L. D., Report of Committee in charge of the Experiment Station, Hawaiian Sugar Planters' Assoc., p. 44, 1948.

3. Borden, R. J., The effects of boron on sugarcane, Experiment Station Committee Report of 1944 Hawaiian Sugar Planters' Association p. 51, 1944.

4. - Sodium chloride on 32-8560 cane, Experiment Station Committee Report of 1945, Hawaiian Sugar Planters' Association, pp. 48-9, 1945.

5. Cibes, H., and Samuels, G., Mineral deficiencies in acerola trees, Agricultural Experiment Station, University of Puerto Rico, Technical Paper 14, 1956.

6. Doty, R. E., Iron sulfate spray for coral chlorosis, Hawaiian Planters' Rec. 34 79-82, 1930.

7. - The effect of lime applications on juice quality, Hawaiian Planters' Rec. 39 326-32, 1935.

8. Hopkins, E. F., Pagán, V., and Ramírez-Silva, F. J., Iron and manganese in relation to plant growth and their importance in Puerto Rico, J. Agr. Univ. P. R. 28 43-101, 1944.

9. Landrau, P., Jr., and Samuels, G., The effect of fertilizers on the yield and quality of sweetpotatoes, J. Agr. Univ. P.R. 35 (2) 71-86, 1951.

10. Landrau, P., Jr., Samuels, G., and Rodríguez, J. P., Influence of fertilizer minor elements, and soil $\mathrm{pH}$ on the growth and protein content of tropical kudzu, J. Agr. Univ. P. R. 37 (1) 81-95, 1953.

11. Martin, J. P., Boron deficiency symptoms in sugarcane, Hawaiian Planters' Rec. 38 95-107, 1934.

12. McGeorge, W. T., The influence of aluminum, manganese, and iron salts upon the growth of sugarcane, and their relation to the infertility of acid Island soils, Hawaiian Sugar Planters' Assoc. Exp. Station, Agr. and Chem. Series Bul. 49, 1-92, July 1925.

13. Pennock, W., Field response of red spanish pineapples to nitrogen, calcium, iron, and soil pH, J. Agr. Univ. P. R. 33 1-26, 1949.

14. Ramírez-Silva, F. J., The effect of certain micronutrient elements on the growth and yield of pineapple plants, J. Agr. Univ. P. R. 30 197-250, 1946.

15. Samuels, G., and Landrau, P., Jr., Potassium competition in a kudzu-Merker grass association, J. Agr. Univ. P.R. 38 (4) 273-382, 1953.

16. - The effect of differential sugarcane fertilizer treatment on a Coloso silty clay, J. Agr. Univ. P. R. 38 179-87, 1954.

17. Schappelle, N. A., The effect of $\mathrm{pH}$ and of certain minor elements on the growth of pineapples in water cultures, J. Agr. Univ. P. R. 26 (3) 63-72, 1942. 